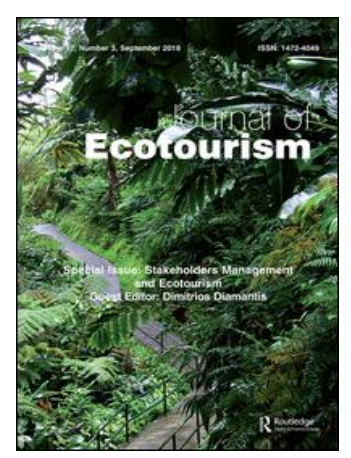

Journal of Ecotourism

\title{
An innovative model for environmental interpretation in freshwater ecosystems: the case of a solar-wind cruise through Lake Sanabria (NW Spain)
}

\author{
Ana Maria Antão-Geraldes, Antonio Oterino Guillén \& David de Salvador \\ Velasco
}

To cite this article: Ana Maria Antão-Geraldes, Antonio Oterino Guillén \& David de Salvador Velasco (2018): An innovative model for environmental interpretation in freshwater ecosystems: the case of a solar-wind cruise through Lake Sanabria (NW Spain), Journal of Ecotourism, DOI: 10.1080/14724049.2018.1492127

To link to this article: https://doi.org/10.1080/14724049.2018.1492127

曲 Published online: 02 Jul 2018.

Submit your article to this journal 주

III Article views: 31

View Crossmark data $₫$ 


\title{
An innovative model for environmental interpretation in freshwater ecosystems: the case of a solar-wind cruise through Lake Sanabria (NW Spain)
}

\author{
Ana Maria Antão-Geraldes (1D ${ }^{a}$, Antonio Oterino Guillén ${ }^{b}$ and David de Salvador \\ Velasco ${ }^{b}$ \\ ${ }^{a}$ CIMO, Escola Superior Agrária, Instituto Politécnico de Bragança, Bragança, Portugal; ${ }^{b}$ EUROPARQUES - \\ Estación/Estação Biológica Internacional, Frontera de Zamora (Spain)/Miranda Do Douro (Portugal)
}

\section{Introduction}

Ana Maria Antão-Geraldes earned her Ph.D. Biology and Ecology from Lisbon University with emphasis on Limnology. Her research interests are mainly focused on the sustainable management, conservation and bioremediation of freshwater ecosystems and on environmental education.

Antonio Oterino Guillén is the Scientific Director of the EBI. Professor of Sciences with a Ph.D in Biology. Expert on freshwater ecosystems, he altruistically coordinates the multidisciplinary team of volunteers and researchers of various nationalities who collaborate in the scientific projects of the EBI. He also coordinates the projects the Virtual Biodiversity Microscopic World Gallery and the "Proyeto Agua"

David de Salvador Velasco is both the founder and the Coordinator of the Europarques Project (since 1994) and of the Duero-Douro International Biological Station (EBI) since 2002. David is a therapist and earned a Master degree in management and conservation of wild fauna from Universities of Leon (Spain) and of Trás-os-Montes and Alto Douro (Portugal). His training and experience, together in the field of conservation and assisted psychotherapy with fauna, have been key to his work as head of the EBI and to development of educational and touristic programs also concerning people with special needs.

Sanabria Lake $\left(42^{\circ} 07^{\prime} 30^{\prime \prime} \mathrm{N} ; 06^{\circ} 43^{\prime} 00^{\prime \prime} \mathrm{W}\right.$; altitude $\left.1000 \mathrm{~m}\right)$ is the largest natural lake in the Iberian Peninsula, located in Spain, in the north-west of the province of ZamoraAutonomous Region of Castilla-Léon (Figures 1 and 2). It is of glacial origin and has a maximum depth of $53 \mathrm{~m}$. The mean water volume of the lake, which occupies an area of about $3.5 \mathrm{~km}^{2}$, is $96.3 \mathrm{Hm}^{3}$ (water residence time (1942-1993): 0.76 years). This lake is not an enclosed lake, being fed by the Tera River and its Cárdenas and Segundera tributaries. It is part of the protected area of the Sanabria Lake Natural Park, also part of the Natura 2000 network.

Similar to other Iberian rural territories, mostly those located in the inland and border areas, this region is continuously losing population for several decades (Almonte \& PazosGarcía, 2016). Most of the year around the lake there are about 200 inhabitants, but in summer, this Natural Park is subject to great tourist pressure (according to Junta de 


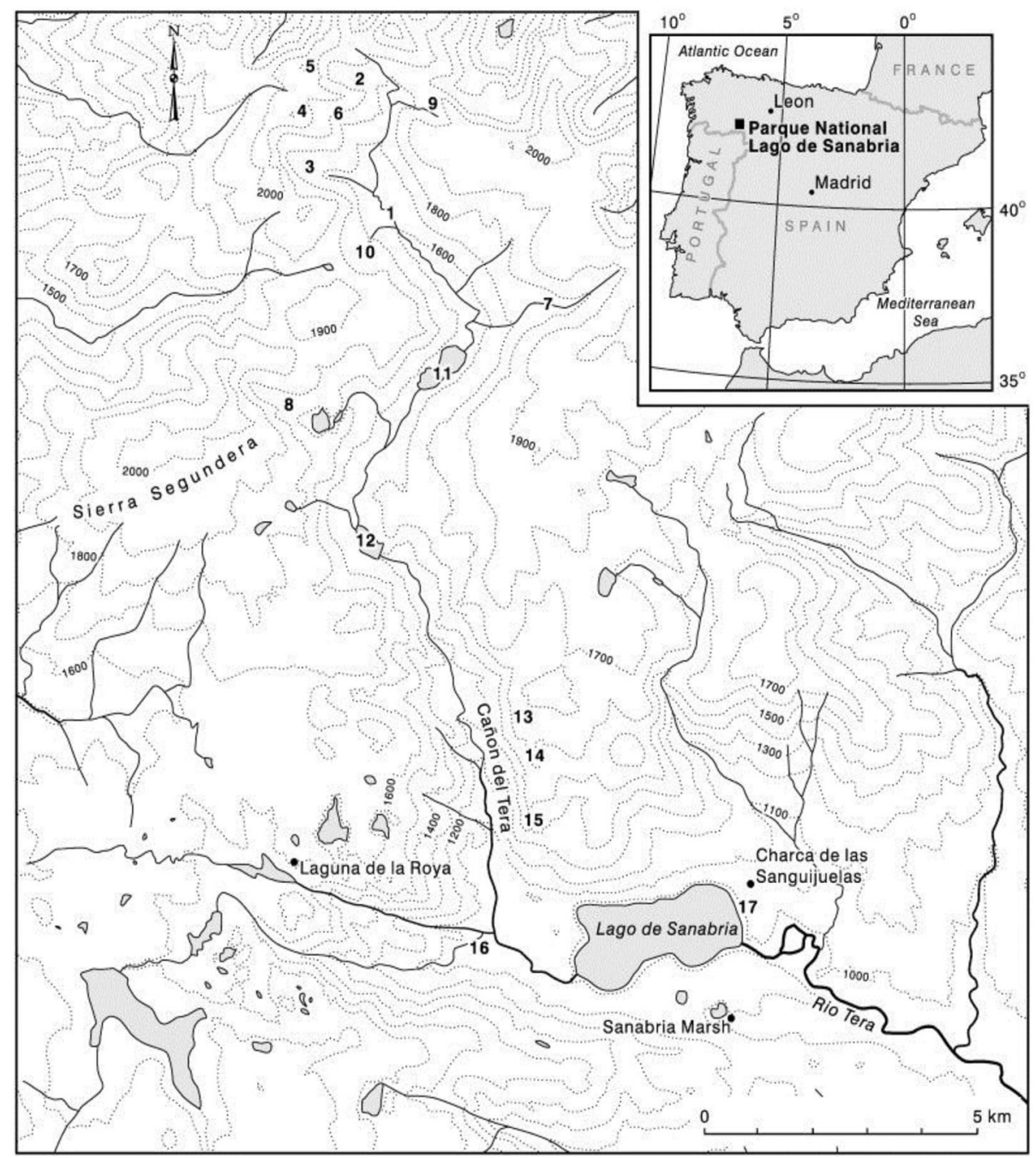

Figure 1. Location of Sanabria Lake (map source: Cowton, Hughes, \& Gibbard, 2009).

Castilla y Leon (2015) more than 600,000 people visited the Park in this present year). Therefore, Lake Sanabria is a very important socioeconomic resource for the inhabitants of its surroundings, representing the main tourist attraction of this region. Besides, it offers different environmental and ecosystem services, having a high biodiversity and, like all oligotrophic mountain lakes, is an extremely sensitive ecosystem (Guillén Oterino, 2015; Jambrina-Enríquez, Recio, Vega, \& Valero-Garcés, 2017; Negro, De Hoyos, \& Vega, 2000). Recreational activities on, in and along freshwaters can stress aquatic ecosystems (Venohr et al., 2018). Therefore, a question arises: how to balance recreational/educational activities in freshwater ecosystems, disturbances and ecological integrity?

A good example of the very few projects that aim to conciliate recreational and educational activities with the conservation of freshwater ecosystems is the ecotourism and educational project for the interpretation of Lake Sanabria implemented by Estación-Estación Biológica Internacional Duero - Douro, which can be replicated in other aquatic 


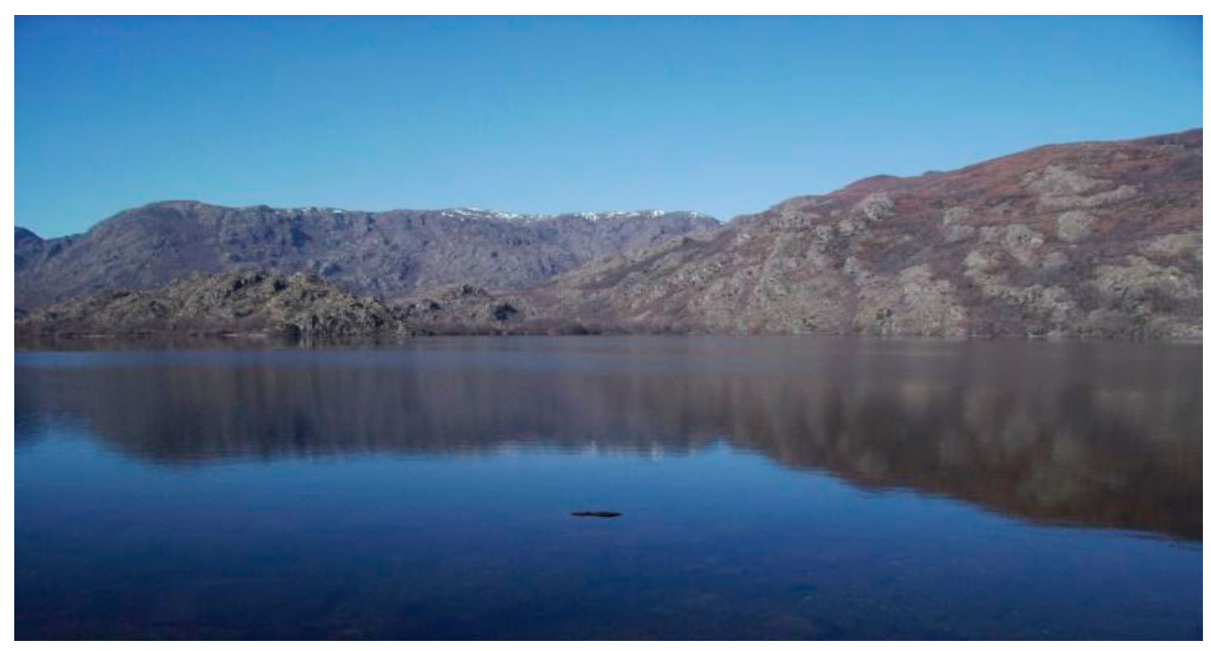

Figure 2. Sanabria Lake.

ecosystems around the world. Therefore, the objective of this field note is to disclose this unconventional and innovative project, that reveals to the general public the functioning and ecology of the freshwater ecosystems, against the backdrop of Lake Sanabria and the surrounding region.

\section{Estación-Estação Biológica Internacional Duero-Douro}

Freshwater ecosystems are biodiversity 'hotspots' and offer a wide range of services to humanity, with emphasis on water and food supplies, aesthetic and spiritual stimuli, and water purification (MEA, 2005) However, on the whole, many of these ecosystems and the associated biodiversity are significantly threatened. Indeed, a large percentage of the world's threatened species occurs in freshwater ecosystems. As a consequence of the loss of biodiversity, the services of these ecosystems can undergo a rapid degradation (Dudgeon et al. 2006; Reid, Contreras MacBeath, \& Csatádi, 2013; WWF, 2014). Despite the proven vital importance of the freshwater ecosystems to humanity - even those that are heavily modified, such as the reservoirs - their functioning and the dwelling species are still little known to the general public. This lack of awareness limits, in many ways, actions leading to the conservation and rehabilitation of these ecosystems. This is due to the fact these freshwater ecosystems did not have had a 'Jacques Cousteau' to make the public aware of the intrinsic, ecological and aesthetic values of them (Monroe, Baxter, Olden, \& Angermeier, 2009). Therefore, to the general public, many freshwater species are 'invisible' and are 'far from the heart.' A paradoxical case is the autochthonous fish species of the Iberian freshwater ecosystems: few people know that these species are endemic - and therefore, unique and, moreover, they play an extremely important role in the ecosystem functioning (Macedo-Veiga, 2013; Sousa-Santos et al., 2016). Thus, if there is no greater public awareness, these ecosystems will continue to be unknown and undervalued by the citizens, who see them only as 'water reservoirs' for the satisfaction of the human needs (Angiel \& Angiel, 2015). The promotion of education and environmental interpretation activities, whether or not they are part of sustainable tourism 
projects, can help to alter citizens' perception of freshwater ecosystems (Hvenegaard, 2017; Padrão \& Tavares, 2014; Walter, 2013). Through the analysis of extensive bibliography, positive results in the alteration of perception regarding the functioning of marine ecosystems have been observed as a consequence of the implementation of cetacean observation activities in the scope of ecotourism projects. This finding supports the urgent need for the implementation of structured environmental education/education programs both within the framework of ecotourism projects and in the context of educational projects (Lück, 2003).

The 'Estación - Estação Biológica Internacional Duero-Douro' (EBI - http://www. duerodouro.org/ is a private organization whose mission is promoting the sustainable economic development of the cross-border marginal regions located in International River Douro Basin. This mainly occurs through the development of ecotourism projects. Recently, in 2015, this geographic area was included in a broader protected area: The Meseta Iberica Transborder Biosphere Reserve - MaB UNESCO (http://www.biosferamesetaiberica.com/es or http://www.biosfera-mesetaiberica.com/pt-pt) The main ecotourism projects developed by EBI are the Environmental Cruises in Arribas do Douro (Natural Park International Douro Natural Park - Portugal and Arribes del Duero Spain) and in the Sanabria Lake (Sanabria Lake Natural Park - Spain near the border with Portugal). The EBI employs 8-10 employees throughout the year, recruiting another 6 during the high season, operating throughout the year, adapting the number of trips to the demanding of visitors. Currently, EBI generates a total of around 70,000 visitors per year, of which about $95 \%$ participate in the environmental cruises. These visits have important positive impacts on the regional cross-border economy of the two countries - Spain and Portugal - generating around three million euros per year in commerce, catering and local accommodation. The obtained revenues are fully reinvested in the region. About $25 \%$ of the income is intended to finance social projects (e.g. therapeutic programs for local children with special needs) and education/environmental awareness projects, such as the long-term monitoring of the Sanabria Lake. The main results of this exhaustive and continuous work were published in the book 'Lago de Sanabria presente y futuro de un ecosistema en desequilibrio' (Guillén Oterino, 2015). This work documented the occurrence, for the first time in the lake, of numerous phytoplankton, phytobenthic and zooplankton species. Some of these species were also referenced for the very first time to the Iberian Peninsula. The occurrence of these species was also published 'online' World Gallery on the Virtual Biodiversity site (http://www. biodiversidadvirtual.org/micro/ and in the 'Proyeto Agua' (https:/www.flickr.com/ photos/microagua/) Both sites are intended to make known to the general public the

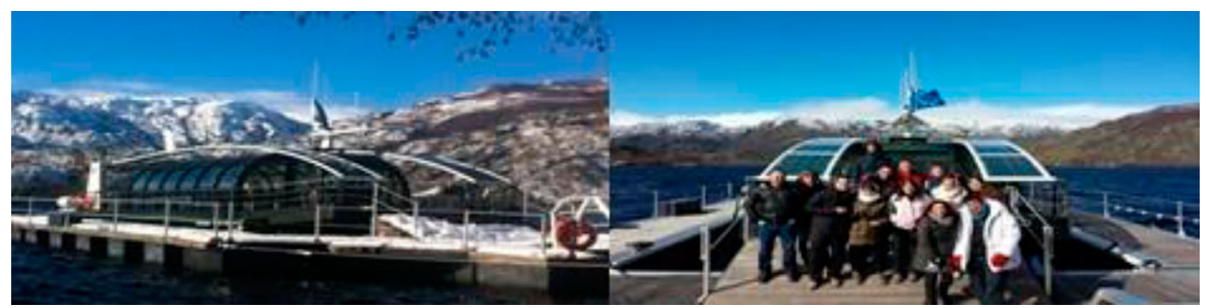

Figure 3. HELIOS. 


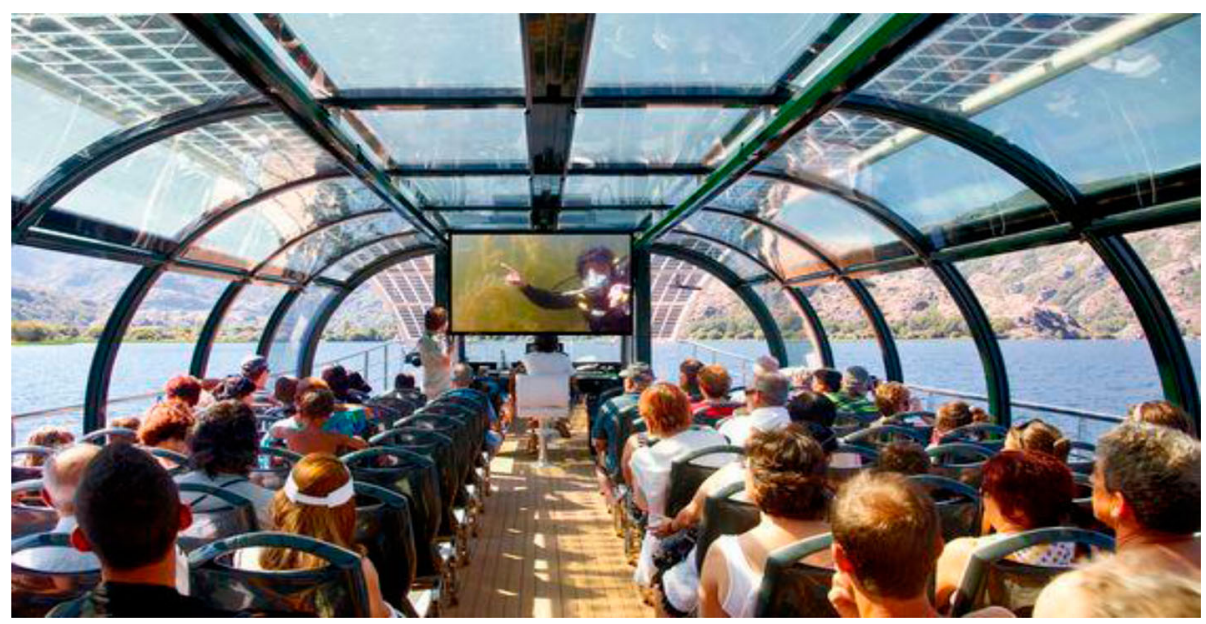

Figure 4. Interpretative diving.

importance of plankton and other microscopic aquatic organisms for the maintenance of the ecological integrity of the lakes. It should be stressed that the 'Proyeto Agua' has so far had more than 12 million of visitors and 1.4 million of online followers.

\section{An environmental/educational cruise in Sanabria Lake: In search of the lake's occulted secrets...}

The main objective of this environmental/educational cruise is the underwater interpretation of the lake. This activity is carried out on board the HELIOS, an 80-seat wind-solar hydroelectric ship equipped with the latest technology (Figure 3). As well as being the first commercial wind-solar ship built in the world, it is environmentally certified, guaranteeing zero emissions of waste, effluents, gases to the atmosphere and noise, thus reducing the environmental impacts of these activities in an extremely sensitive ecosystem such as the Sanabria Lake (e.g. Gürsu, 2014).

During the trip technicians of the EBI perform the underwater interpretation of the lake with a living diving (Figure 4). A complex video and communication system allows the diver and tourists to communicate between them. Therefore, tourists can obtain realtime information concerning lake geology and underwater flora and fauna. Concomitantly, participants also attend a lake monitoring session, where several environmental parameters are determined and plankton samples are taken. The interpretation of plankton and other microscopic organisms - with a key role in the functioning of the lake - is performed with the aid of a microscope coupled to an image screen (Figure 5). The trip ends with tasting locally produced cider. This activity is accessible to people with reduced mobility. Schools of all educational levels may also have access to this Cruise for free or at very reduced prices.

\section{Opportunities, challenges and perspectives}

There are challenges to the future for both - traditional tourism and ecotourism - in Sanabria Lake. These can only be overcome through the cooperation between operators, 


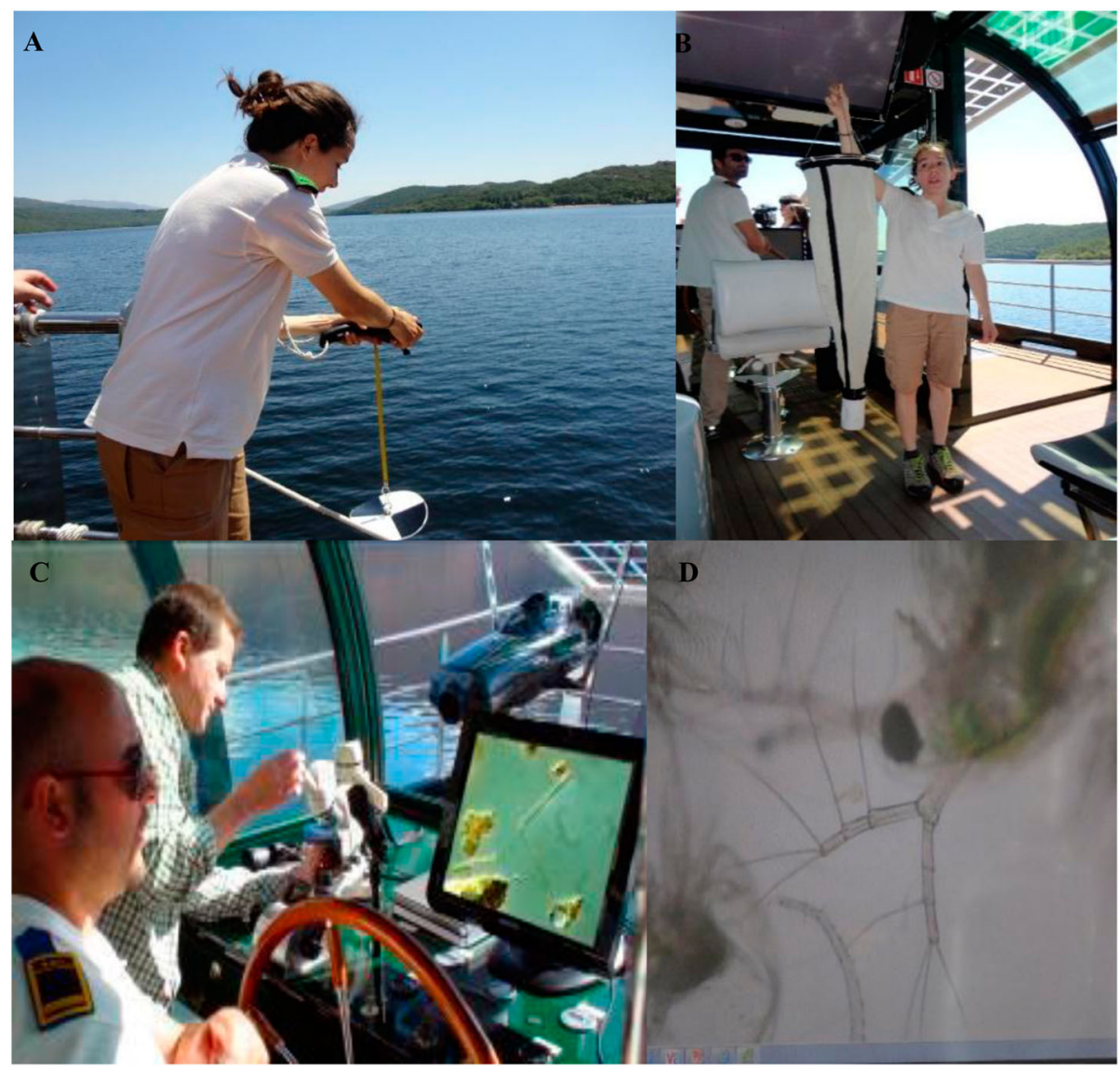

Figure 5. Measuring Secchi depth (A); Plankton sampling net (B); Plankton observation (C, D).

public administration (e.g. park management sector, municipalities, national and European entities) and academia. Indeed, current management approaches addressing economic, environmental or Recreational aspects are poorly linked and harmonized, and are further constrained by inadequate information on the dynamics and densities of the recreational uses. Therefore, because recreational use and the impacts on the lake are not treated in an integrative manner across administrative and academic sectors, current conservation strategies are also insufficient to stop environmental degradation, mitigate negative impacts and may at the same time even harm the quality of the cultural and ecological services provided by this particular lake. Like other mountain aquatic ecosystems Sanabria Lake is very sensitive to human disturbance. The impact of tourism activities in aquatic ecosystems are well documented (e.g. Free et al., 2014; Schmeller et al., 2018; Venohr et al., 2018); however, for this lake, concrete published data concerning the impact of tourists visiting the lake seems to be nonexistent. Consequently, it is impossible the promotion of efficient management plans to regulate the tourist flows. Mediterranean mountain lakes have been repeatedly identified as being susceptible to accelerated anthropogenic climatic change. This is due in part to increased summer mean air temperature and reduced annual precipitation heightening the risk of summer drought in the in this region (Jiménez, 
Rühland, Jeziorski, Smol, \& Pérez-Martínez, 2017), leading to profound changes in aquatic ecosystems with potential severe consequences for the ecosystem services they provide (Williamson, Saros, Warwick, \& Smol, 2009). This could undermine future tourism operations and activities (e.g. Ooi, Duke, \& O’Leary, 2018; Scott, Jones, \& Konopek, 2007) Therefore, it is urgent to investigate how the potential effects of climate change will affect tourism in Lake Sanabria, in order to develop novel strategies and opportunities given this threat.

\section{Conclusion}

This project is an example of how it is possible to develop innovative projects combining sustainable tourism, environmental education and interpretation, and concomitantly, promoting the sustainable economic development of the cross-border marginal regions of Portugal and Spain. Recently, under the scope of the project 'One River, Two Countries,' this model of environmental interpretation was also implemented in Douro International Natural Park. In order to improve its ecotourism experience and to guide its programing and investment, EBI intends to develop studies that will allow it to: (1) examine participants' motivations; (2) determine the impact of the experience on participants' awareness, knowledge, attitudes, and behavioral changes, if any, towards aquatic ecosystems; and, (3) understand what activities tourists to the area are searching for and whether or not these activities are specifically linked to aquatic ecosystems.

Unfortunately, organizations with a philosophy and innovative ecotourism product similar to that of EBI are still marginal in national and international tourism panoramas. Despite this challenge, the value of sustainable tourism projects is increasingly recognized due to the synergies between nature, place, and the people that this kind of tourism promotes (e.g. Hvenegaard, 2017; Lück, 2003). Nevertheless, any approach to developing novel ecotourism products or projects needs to take in account the ecosystem specificities and fragilities in order to reduce the potential conflicts between lake conservation and touristic uses.

\section{Disclosure statement}

No potential conflict of interest was reported by the authors.

\section{ORCID}

Ana Maria Antão-Geraldes (D) http://orcid.org/0000-0003-4966-2227

\section{References}

Almonte, J. M. J., \& Pazos-García, F. J. (2016). Population and rural tourism in low demographic density territories in Spain. Boletín de la Asociación de Geógrafos Españoles, 71, 511-514.

Angiel, J., \& Angiel, P. J. (2015). Perception of river value in education for sustainable development (The Vistula River, Poland). Sustainable Development, 23, 188-201.

Cowton, T., Hughes, P. D., \& Gibbard, P. L. (2009). Palaeoglaciation of Parque Natural Lago de Sanabria, northwest Spain. Geomorphology, 108(3/4), 282-291. 
Dudgeon, D., Arthington, A. H., Gessner, M. O., Kawabata, Z., Knowler, D. J., Lévêque, C., \& Sullivan, C. A. (2006). Freshwater biodiversity: Importance, threats, status and conservation challenges. Biological Reviews, 81(2), 163-182.

Free, C. M., Jensen, O. P., Mason, S. A., Eriksen, S. A., Nicholas, J. M., Williamson, N. J., \& Boldgiv, B. (2014). High-levels of microplastic pollution in a large, remote, mountain lake. Marine Pollution Bulletin, 85, 156-163.

Guillén Oterino, A. (2015). Lago de Sanabria presente y futuro de un ecosistema en desequilibrio. Estación Biológica internacional 'Duero-Douro'. Retrieved from http://www.duerodouro.org/ area-de-investigacion/investigacion-lago-de-sanabria/indice

Gürsu H. (2014). Solar and wind powered concept boats: The example of Volitan. Metu JFA 31(2), 109-123.

Hvenegaard, T. (2017). Visitors' perceived impacts of interpretation on knowledge, attitudes, and behavioral intentions at Miquelon Lake Provincial Park, Alberta, Canada. Tourism and Hospitality Research, 17(1), 79-90.

Jambrina-Enríquez, M., Recio C., Vega, J. C., \& Valero-Garcés, B. (2017). Tracking climate change in oligotrophic mountain lakes: Recent hydrology and productivity synergies in Lago de Sanabria (NW Iberian Peninsula), Science of the Total Environment, 590-591, 579-591.

Jiménez, L., Rühland, K. M., Jeziorski, A., Smol, J. P., \& Pérez-Martínez, C. (2017). Climate change and Saharan dust drive recent Cladoceran and primary production changes in remote alpine lakes of Sierra Nevada, Spain. Global Change Biology, e139-e158. doi:10.1111/gcb.13878

Junta de Castilla y Leon. (2015). El Parque Natural del Lago de Sanabria recibió el pasado año un 7\% más de visitantes in. Retrieved from http://www.comunicacion.jcyl.es/web/jcyl/Comunicacion/ es/Plantilla100Detalle/1281372051501/_/1284565307491/Comunicacion

Lück, M. (2003). Education on marine mammal tours as agent for conservation - but do tourists want to be educated? Ocean \& Coastal Management, 46, 943-956.

Macedo-Veiga, A. (2013). Towards the conservation of freshwater fish: Iberian rivers as an example of threats and management practices. Reviews in Fish Biology and Fisheries, 23, 1-22.

Millenium Ecosystem Assessment (MEA). (2005). Ecosystems and human well-being: Synthesis. Washington, DC: Island Press.

Monroe, J. B., Baxter, C. V., Olden, J. D., \& Angermeier, P. L. (2009). Freshwaters in the public eye: Understanding the role of images and media in aquatic conservation. Fisheries, 34(12), 581-585.

Negro, A. I., De Hoyos, C., \& Vega, J. C. (2000). Phytoplankton structure and dynamics in Lake Sanabria and Valparaíso reservoir (NW Spain). Hydrobiologia, 424, 25-37.

Ooi, N., Duke, E. \& O'Leary, J. (2018). Tourism in changing natural environments. Tourism Geographies, 20(2), 193-201. doi:10.1080/14616688.2018.1440418

Padrão J. \& Tavares, J. (2014). Environmental education and tourism. Mediterranean Journal of Social Sciences, 5(22), 540-544.

Reid, G., Contreras MacBeath, T., \& Csatádi, K. (2013). Global challenges in freshwater-fish conservation related to public aquariums and the aquarium industry. International Zoo Yearbook, $47,6-45$.

Schmeller, D. S., Loyau, A., Bao, K., Brack, W., Chatzinotas, A., De Vleeschouwer, F.,... Vredenburg, V. T. (2018). People, pollution and pathogens - global change impacts in mountain freshwater ecosystems. Science of the Total Environment, 622-623, 756-763.

Scott, D., Jones, B., \& Konopek, J. (2007). Implications of climate and environmental change for nature-based tourism in the Canadian Rocky Mountains: A case study of Waterton Lakes National Park. Tourism Management, 28, 570-579.

Sousa-Santos, C., Robalo, J. I., Pereira, A. M., Branco, P., Santos, J. M., Ferreira, M. T., ... Doadrio, I. (2016). Broad-scale sampling of primary freshwater fish populations reveals the role of intrinsic traits, inter-basin connectivity, drainage area and latitude on shaping contemporary patterns of genetic diversity. PeerJ,4, e1694. doi:10.7717/peerj.1694

Venohr, M., Langhans, S. D., Peters, O., Hölker, F., Arlinghaus, R., Mitchell, L., \& Wolter, C. (2018). The underestimated dynamics and impacts of water-based recreational activities on freshwater ecosystems. Environmental Reviews. doi:10.1139/er-2017-0024 
Walter, P. G. (2013). Theorising visitor learning in ecotourism. Journal of Ecotourism, 12(1), $15-32$.

Williamson, C. E., Saros, J. E., Warwick, V. F., \& Smol, J. P. (2009). Lakes and reservoirs as sentinels, integrators, and regulators of climate change. Limnology and Oceanography, 54, Part 2, 22732282.

WWF. (2014). Living planet report 2014. Gland, Switzerland: Author. 